\title{
Reproductive biology of the armored catfish Neoplecostomus microps in a coastal Atlantic Forest stream, southeastern Brazil
}

\author{
Víctor de Carvalho Alves ${ }^{1,2, *}$, Marcelo Fulgêncio Guedes Brito ${ }^{3}$, \\ Erica Pellegrini Caramaschi ${ }^{1}$ \\ ${ }^{1}$ Laboratório de Ecologia de Peixes, Departamento de Ecologia, Universidade Federal do Rio de Janeiro, \\ 21941-902 Rio de Janeiro, RJ, Brazil \\ ${ }^{2}$ Fundação Instituto de Pesca do Estado do Rio de Janeiro, 24030-020 Niterói, RJ, Brazil \\ ${ }^{3}$ Programa de Pós-Graduação em Ecologia e Conservação, Universidade Federal de Sergipe, 49100-000 Sergipe, SE, Brazil
}

\begin{abstract}
This work aims to analyze reproductive attributes of the species Neoplecostomus microps (Steindachner, 1877), a well-known species of the catfish family Loricariidae but little contemplated in ecological studies. We describe the reproductive behavior of the species and compare the patterns identified in 2 different basins. The specimens (117 males and 102 females), collected in the Macaé River, did not present a bias in sex ratio during the year. In the largest length classes, males predominated and attained earlier maturity than females. The length-weight relationship showed positive allometric growth for both sexes. The variation of the gonadosomatic index and frequency of maturation stages indicated a reproductive period of 4 to $6 \mathrm{mo}$, starting in September and reaching a peak in November. The mean absolute fecundity was 43.83 (SD = 7.62) oocytes, ranging from 32 to 55 oocytes. The frequency distribution of oocyte diameter of mature ovaries revealed 3 clutches, suggesting batch spawning. A prolonged reproductive period, low fecundity, large eggs, possible parental care, and repeated spawns recorded for $N$. microps suggest a strategy that maximizes parental fitness. The population structure and reproductive characteristics of this species indicate a tendency toward equilibrium. The early maturation in females in the Macaé River population may favor a more rapid replacement of juveniles in the population as a response to the unstable environmental conditions that the population experiences in the rainy season.
\end{abstract}

KEY WORDS: Neoplecostomus microps · Armored catfish $\cdot$ Reproductive biology $\cdot$ Atlantic forest stream · Macaé River

\section{INTRODUCTION}

Loricariid catfishes are important components of the stream ichthyofauna (Buckup 1999) throughout most of the Neotropics (Ferraris 2003a). Their representatives typically inhabit lotic environments (Sterba \& Mills 1983, Sakurai et al. 1993) and consume algae and detritus (Flecker 1992, Power 1984). Distinct from other fish groups, the dispersion of the family occurs almost exclusively at the primary trophic level, with adaptations involving morphology, feeding behavior,

${ }^{*}$ Corresponding author: victorcalves@hotmail.com and digestive processes to exploit sediment and debris, wood rasping, and periphyton (Schaefer \& Lauder 1986, Delariva \& Agostinho 2001). Loricariids have a large diversity of reproductive strategies (functional diversity); there are species with complete absence of parental care, males that carry adhesive eggs and larvae on the ventral surface, and species with nest protection (Suzuki et al. 2000).

Species of the genus Neoplecostomus are distributed in rivers and streams in south-central Brazil (Ferraris 2003b, Buckup 2007, Zawadzki et al. 2008).

() The authors 2019. Open Access under Creative Commons by Attribution Licence. Use, distribution and reproduction are unrestricted. Authors and original publication must be credited. 
The genus comprises 17 species (Eschmeyer et al. 2016), and little is known of their biology and ecology. Neoplecostomus microps occurs in the Paraíba do Sul basin (Langeani 1990, Bizerril 1995) and adjacent coastal rivers (Buckup 2007), in fast-flowing stretches with stones and boulders (Brito et al. 2016). Recently, studies on distribution pattern, sexual dimorphism, nesting sites, and some reproductive attributes were published for populations in the Paraíba do Sul and Macaé River basins (Braga et al. 2008, Brito et al. 2016).

The limited number of reports on reproduction of small loricariid catfishes from creeks and streams is due to sampling difficulties for these studies. In this study, we analyzed the population structure and reproduction characteristics of $N$. microps in a rocky and forested coastal stream of the state of Rio de Janeiro, Brazil. We focused on population length structure, length-weight relationship, macroscopic characteristics of gonads, reproductive period, size at first gonad maturation, and fecundity.

\section{MATERIALS AND METHODS}

\subsection{Study site}

We sampled the Macaé River $\left(22^{\circ} 21^{\prime}-22^{\circ} 28^{\prime} \mathrm{S}\right.$ and $42^{\circ} 27^{\prime}-42^{\circ} 35^{\prime} \mathrm{W}$ ), a $110 \mathrm{~km}$ long coastal stream located in Rio de Janeiro State, southeastern Brazil. This is a mediumsized river located on the coastal slope of the Serra do Mar. This basin has dense drainage, is located in a humid tropical region, and is surrounded by Atlantic Forest vegetation. The headwaters lie between 810 and $1090 \mathrm{~m}$ above sea level. The upper and middle courses of the Macaé River and its tributaries are dominated by rapids and waterfalls, with stony beds between sandy pools (Brito 2007). During the study period, the highest rainfall values occurred from November to March.

\subsection{Sampling}

Specimens of Neoplecostomus microps were collected in rapids at 8 sites (Fig. 1) equally distributed throughout the upper and middle stretches of the river using a rectangular frame net $(1.5 \times 1 \mathrm{~m} ; 5 \mathrm{~mm}$ mesh), with a standardized effort of 10 bins at each of the sampling points (Brito et al. 2016). Samples were taken every 2 mo, between March 2004 and March 2005, at the middle course of the Macaé River. The specimens were fixed in $10 \%$ formalin and later transferred to $70 \%$ ethanol. In the laboratory, the specimens were measured, weighed, and sexed, and the reproductive stages were classified.

Voucher specimens were deposited in the fish collection of the Museu Nacional do Rio de Janeiro (MNRJ 39018).

\subsection{Population structure analysis}

For each specimen, the standard length $\left(L_{\mathrm{s}}\right)$ was recorded. Standard length structure analyses were determined from the number of individuals in different size classes. The classes were established with $0.5 \mathrm{~cm}$ intervals. The length-weight relationship, $W_{\mathrm{t}}=a L_{\mathrm{s}}{ }^{b}$, where $W_{\mathrm{t}}=$ total weight, $L_{\mathrm{s}}=$ standard length, $a=$ intercept, and $b=$ isometric coefficient, was $\log$ transformed to $W_{\mathrm{t}}=\log a+\log b \times L_{\mathrm{s}}$ (Lleonart et al. 2000). Relationships between standard length and weight were determined by linear regression. The $95 \%$ confidence limits for $b$ were calculated to determine whether the hypothetical value

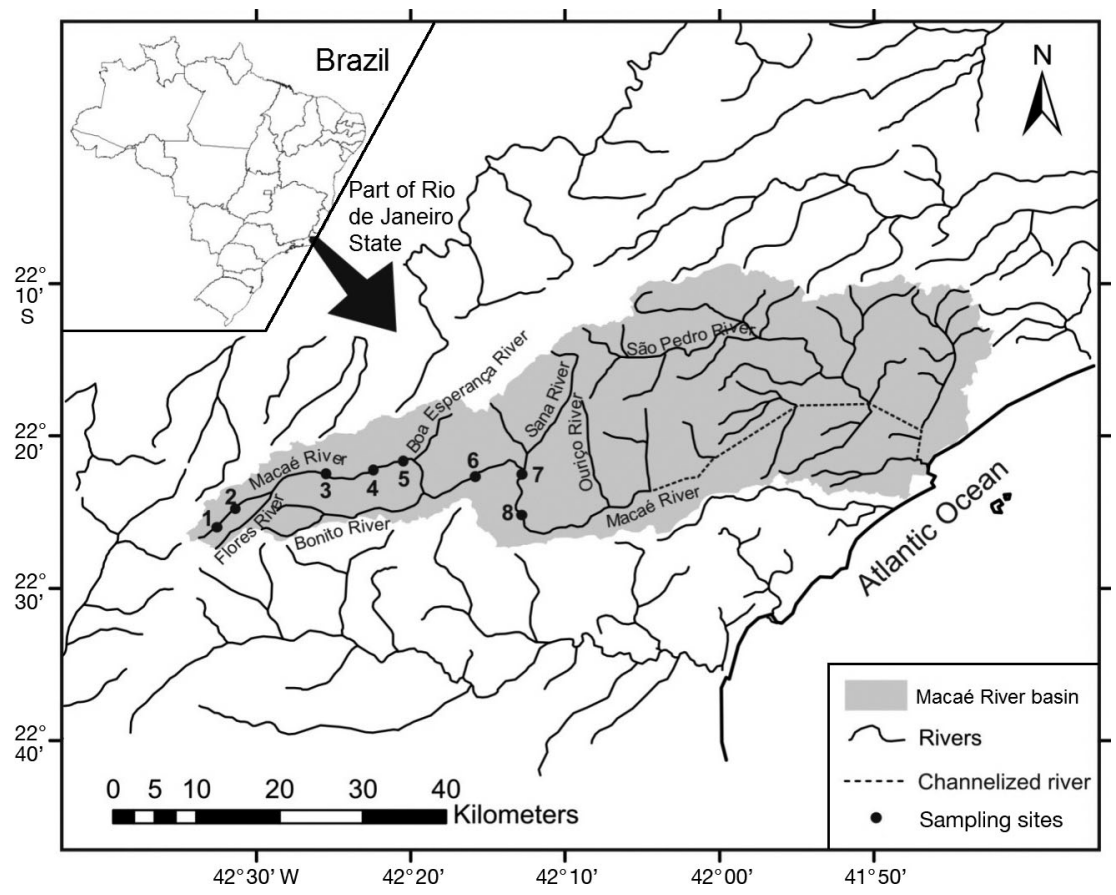

Fig. 1. Sampling sites for Neoplecostomus microps in Macaé River basin, Rio de Janeiro State, southeastern Brazil 
of isometry (3) fell within these limits (Froese 2006). In all cases, a significance level $(\alpha)$ of $5 \%$ was adopted. The significance of the regression was tested by ANOVA to check whether the calculated value of $b$ is significantly different from 3 (isometric value).

\subsection{Sex and reproductive analysis}

For each specimen, the total weight $(W \mathrm{t})$, gonad weight $(W g)$, sex, and reproductive stage were recorded. Sex and reproductive stage were categorized according to macroscopic features, including color, presence of blood vessels, presence of oocytes, and size of the gonad (Vazzoler 1996). The reproductive stages were defined as immature, maturing, mature, partially spent, spent, and resting for males and immature, maturing, mature, partially spawned, spawned, and resting for females, according to the macroscopic scale suggested by Núñez \& Duponchelle (2009), with 5 or 6 stages. The macroscopic criteria used in this study were similar to other loricariids (Agostinho et al. 1991, Menezes \& Caramaschi 1994, Dei Tos et al. 1997, Mazzoni \& Caramaschi 1997, Guimarães-Cruz et al. 2005), with 6 stages of gonad maturity for both sexes. Reproductive aspects of the $N$. microps population were characterized by the following: reproductive period, size at first gonad maturation, macroscopic analysis of gonads, and fecundity. The reproductive period was determined through analysis of the variation of the gonadosomatic index $\left(\mathrm{GSI}=\left(W_{\mathrm{g}} / W_{\mathrm{t}}\right) \times 100\right)$ taken every 2 mo as well as analyses of the relative frequencies of gonadal maturation stages during the sampling period. Size at first gonad maturation was defined as the length class in which $50 \%$ of the specimens were adults, estimated according to the distribution of relative frequencies of young and adult fish by length classes (Vazzoler 1996).

Six mature ovaries were dissociated in a modified Gilson solution (Vazzoler 1996) to estimate the fecundity (number of vitellogenic oocytes per ovary), by the volumetric method described by Vazzoler (1996). The diameter of oocytes from a random sample of each dissociated ovary was obtained under a stereomicroscope, and their frequency distribution $(\mathrm{mm})$ was determined.

\subsection{Statistical analysis}

We checked for differences in the sex ratio within size classes, by means of the chi-square test. GSI and rainfall values were checked using Shapiro-Wilks and Bartlett's tests to verify normality and homoscedasticity of the data. As these specific conditions were not satisfied, non-parametric Kruskal-Wallis analysis of variance followed by the Dunn post hoc test was applied to identify the months that GSI values differed. The non-parametric Spearman's rank correlation test was applied between GSI variation and rainfall values to verify possible relationships. For male and female tests, a significance level of 0.05 was applied (males: Spearman's $=-0.202, p=0.281$; females: Spearman's $=-0.119, \mathrm{p}=0.231$ ). The software used was BioEstat 5.0 (Ayres et al. 2007).

\section{RESULTS}

\subsection{Population structure}

A total of 219 specimens of Neoplecostomus microps were captured, including 117 males and 102 females. Standard length ranged from 3.2 to $9.7 \mathrm{~cm}$ for males and 3.5 to $8.0 \mathrm{~cm}$ for females; males were larger than females (Fig. 2).

The sex ratio did not differ from $1: 1\left(\mathrm{df}=1 ; \chi^{2}=\right.$ 1.027; $\mathrm{p}=0.310$ ), considering months and localities grouped in total, despite the slight predominance of males over females. Considering sex ratio in the different localities, no significant differences were observed (all cases: $\mathrm{df}=1 ; \chi^{2}<3.84 ; \mathrm{p}>0.05$ ), but differences were found in March $2004\left(\mathrm{df}=1 ; \chi^{2}=\right.$ 4.001; $\mathrm{p}=0.045)$ and July $2004\left(\mathrm{df}=2 ; \chi^{2}=4.263 ; \mathrm{p}=\right.$ 0.038 ), with male predominance. For different standard length classes (Fig. 2), the null hypothesis was rejected only for the class 6.5 to $7.0 \mathrm{~cm}$ (sexual proportion: $\mathrm{df}=1 ; \chi^{2}=10.801 ; \mathrm{p}=0.001$ ) with female predominance and for the absence of females over size class 7.5 to $8.0 \mathrm{~cm}$.

The equations for the length-weight relationship, obtained from the biometric data of males and females, were $W_{\mathrm{t}}=0.019 L^{3.0485}\left(\mathrm{r}^{2}=0.992\right)$ and $W_{\mathrm{t}}=$ $0.018 L^{3.059}\left(\mathrm{r}^{2}=0.992\right)$, respectively. For both sexes, the increment of weight relative to length was positively allometric $(b>3.0$; males and females: ANOVA, $\mathrm{p}<0.001)$.

\subsection{Reproduction}

The gonads of both sexes showed variation in size, color, thickness, and angiogenesis, according to the reproductive stage. The testes are paired and dorsally attached by the mesorchium. When immature 


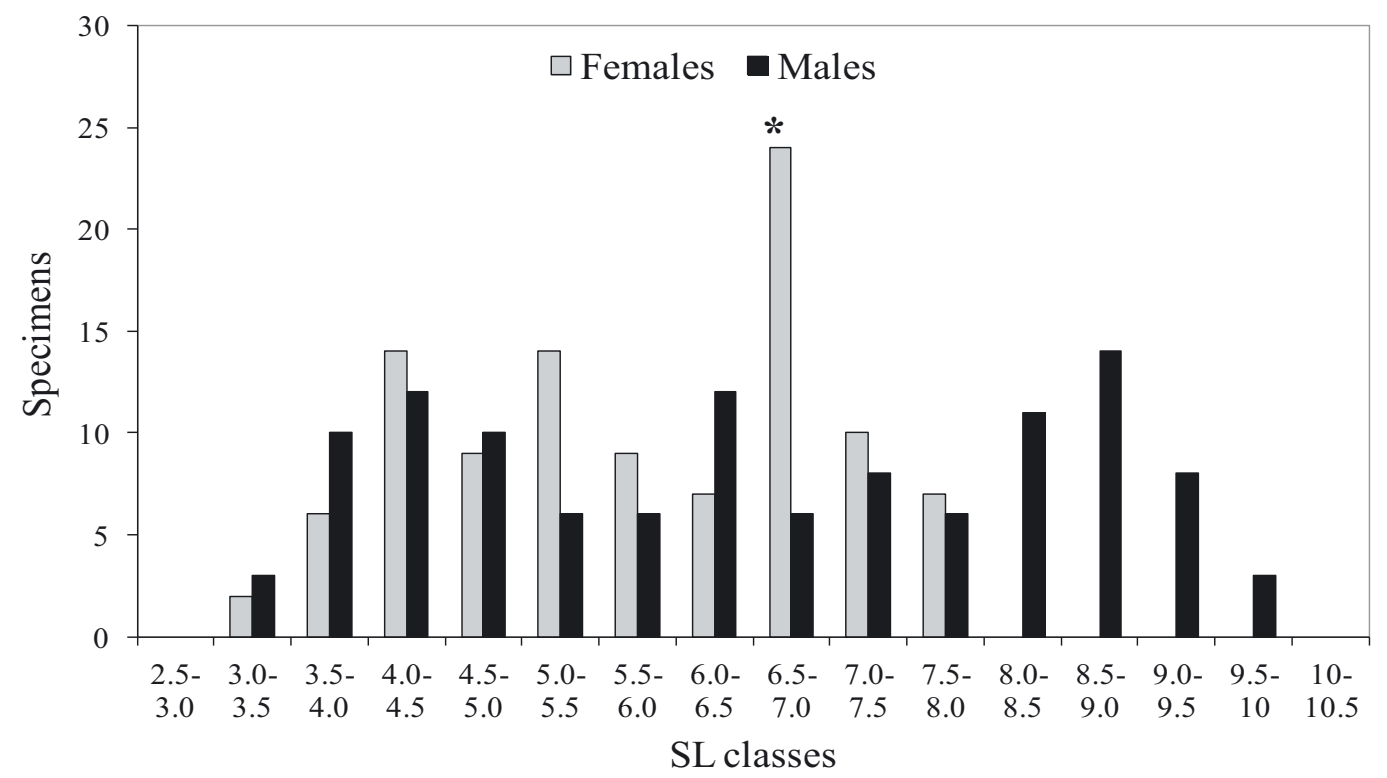

Fig. 2. Distribution of the absolute frequencies of occurrence of females and males of Neoplecostomus microps in the standard length (SL) classes (cm) in the Macaé River, southeastern Brazil, from March 2004 through March 2005. *Significantly different chi-square test; $\mathrm{p}<0.05$
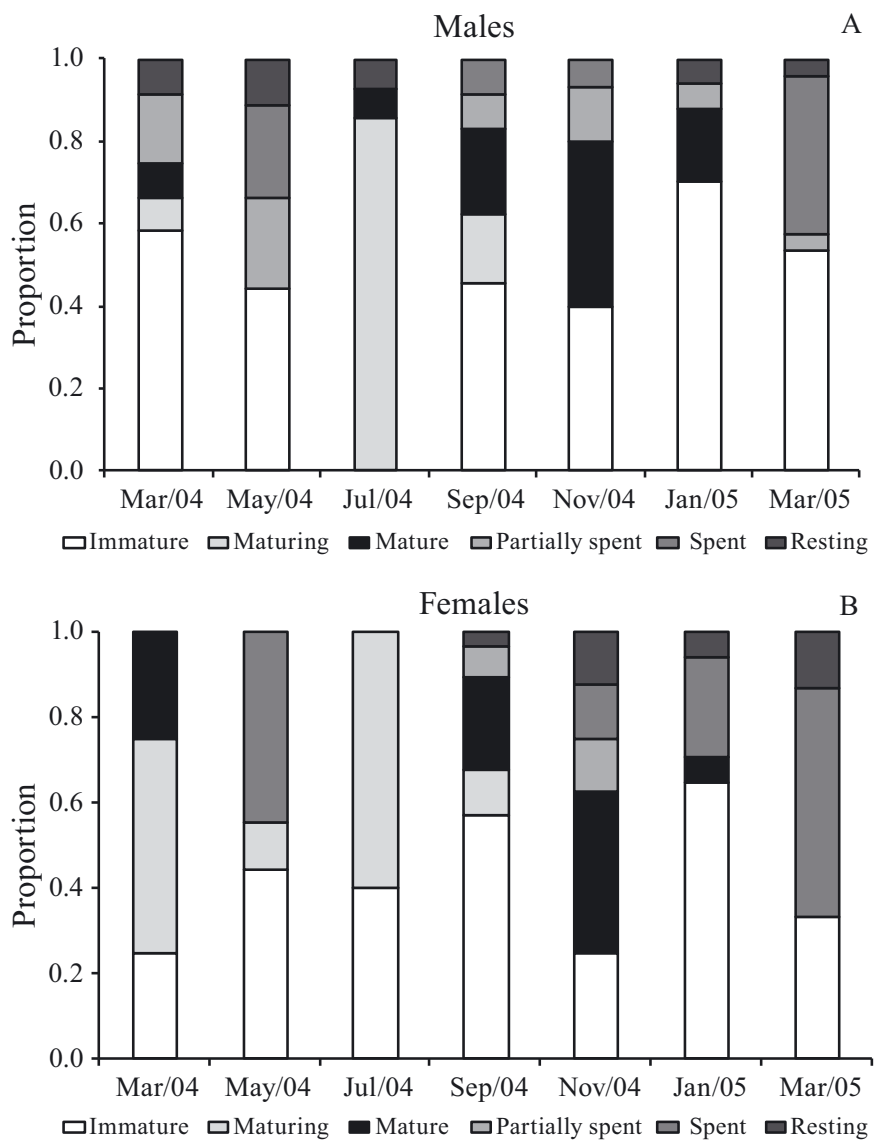

Fig. 3. Distribution of frequency of gonad maturation stages of (A) males and (B) females of Neoplecostomus microps in the Macaé River, southeastern Brazil, from March 2004 through March 2005 or resting, they are filiform and translucent; when maturing, the volume gradually increases until they become turgid, when the fish attain the mature stage (Table 1). The morphological changes in the ovaries are more remarkable than those in the testes. The ovaries of $N$. microps are paired, sacculiform organs, attached dorsally to the body cavity by the mesovarium and joined at the caudal portion (Table 1).

Males of $N$. microps in the Macaé River tended to reach maturity at larger sizes than females. The first gonad maturation was estimated for males at size class 6.6 to $7.0 \mathrm{~cm}$ and for females at 5.9 to $6.2 \mathrm{~cm}$. The relative frequencies of gonad maturation stages showed the presence of immature males and females in all samples, except males in July 2004 (Fig. 3).

The highest numbers of mature individuals of both sexes were found in November 2004 (Fig. 3), coinciding with the peaks of GSI values (Fig. 4). The distribution of mature individuals and the variation of GSI values indicated a breeding season starting in September and peaking in November. For males, GSI values varied from 0.015 to 2.610 and for females from 0.039 to 16.900 . Through the Kruskal-Wallis test, GSI values varied significantly for males $(H=$ 14.884; $\mathrm{df}=6 ; \mathrm{p}=0.021)$ and females $(H=13.014$; $\mathrm{df}=6 ; \mathrm{p}=0.041$ ). By the post hoc test, it was verified for males that March 2005 differed significantly from July $2004(p=0.016)$, September $2004(p=0.018)$, and November $2004(p=0.009)$; January 2005 differed significantly from July $2004(p=0.022)$, Sep- 
Table 1. Gonad development of males and females of Neoplecostomus microps, macroscopically characterized. GSI: gonadosomatic index; SL: standard length

\begin{tabular}{|c|c|c|}
\hline Stage & Development of testes & Development of ovaries \\
\hline Immature & $\begin{array}{l}\text { Filamentous and transparent; occupies less } \\
\text { than } 5 \% \text { of the volume of the abdominal } \\
\text { cavity; sometimes difficult to see. GSI mean } \\
=0.21 \text {; SL mean }=4.58\end{array}$ & $\begin{array}{l}\text { Occupies less than } 10 \% \text { of the abdominal cavity; } \\
\text { translucent; oocytes not visible to the naked eye, } \\
\text { irrigation not visible. GSI mean }=0.06 \text {; SL mean }= \\
4.78\end{array}$ \\
\hline Maturing & $\begin{array}{l}\text { Form is still filamentous but organs are more } \\
\text { conspicuous; occupies between } 5 \text { and } 10 \% \text { of } \\
\text { the abdominal cavity; whitish color, weak } \\
\text { irrigation and slightly flaccid. GSI mean = } \\
0.22 \text {; SL mean }=7.11\end{array}$ & $\begin{array}{l}\text { Occupies between } 20 \text { and } 25 \% \text { of the abdominal } \\
\text { cavity; beige color; some oocytes visible to the } \\
\text { naked eye; moderate irrigation and turgid. GSI } \\
\text { mean }=1.97 ; \text { SL mean }=6.67\end{array}$ \\
\hline Mature & $\begin{array}{l}\text { Flat tubular form and maximum size; } \\
\text { occupies between } 20 \text { and } 25 \% \text { of the } \\
\text { abdominal cavity; white, evident irrigation } \\
\text { and turgid. GSI mean }=1.07 \text {; SL mean }=8.88\end{array}$ & $\begin{array}{l}\text { Maximum size, occupying more than } 70 \% \text { of the } \\
\text { abdominal cavity; yellowish; oocytes visible to the } \\
\text { naked eye in } 3 \text { different size classes (smallest size } \\
\text { corresponds to young oocytes of reserve stock, } \\
\text { intermediate corresponds to developing oocytes, } \\
\text { and largest corresponds to mature vitellogenic } \\
\text { oocytes); oocytes yellow or beige; ovaries with } \\
\text { intense irrigation in blood vessels and very turgid. } \\
\text { GSI mean = 10.57; SL mean }=7.11\end{array}$ \\
\hline $\begin{array}{l}\text { Partially spent/ } \\
\text { partially spawned }\end{array}$ & $\begin{array}{l}\text { Flat tubular form; occupies between } 10 \text { and } \\
15 \% \text { of the abdominal cavity; whitish, and } \\
\text { evident irrigation with hemorrhagic and } \\
\text { flaccid appearance. GSI mean }=0.42 ; \text { SL } \\
\text { mean }=8.29\end{array}$ & $\begin{array}{l}\text { Occupies between } 30 \text { and } 40 \% \text { of the abdominal } \\
\text { cavity; yellowish; oocytes visible to the naked eye } \\
\text { in smaller quantities and translucent; intense } \\
\text { irrigation with hemorrhagic and flaccid appear- } \\
\text { ance. GSI mean }=5.91 \text {; SL mean }=6.96\end{array}$ \\
\hline Spent/spawned & $\begin{array}{l}\text { Flat filamentous and filamentous form; } \\
\text { occupies less than } 10 \% \text { of the abdominal } \\
\text { cavity; whitish; intense irrigation with very } \\
\text { hemorrhagic appearance and very flaccid. } \\
\text { GSI mean }=0.30 ; \text { SL mean }=8.05\end{array}$ & $\begin{array}{l}\text { Occupies approximately } 30 \% \text { of the abdominal } \\
\text { cavity; few unspawned oocytes visible in possible } \\
\text { resorption process; hemorrhagic appearance and } \\
\text { very flaccid. GSI mean }=1.99 \text {; SL mean }=6.70\end{array}$ \\
\hline Resting & $\begin{array}{l}\text { Testes still large as a stage } 4 \text { but flaccid; } \\
\text { empty-like. GSI mean }=0.09 ; \text { SL mean }=7.04\end{array}$ & $\begin{array}{l}\text { Ovaries similar to immature stage but usually } \\
\text { larger, wider, and pink to dark red in color; ovarian } \\
\text { wall also thicker. GSI mean }=0.65 ; \text { SL mean }=5.97\end{array}$ \\
\hline
\end{tabular}
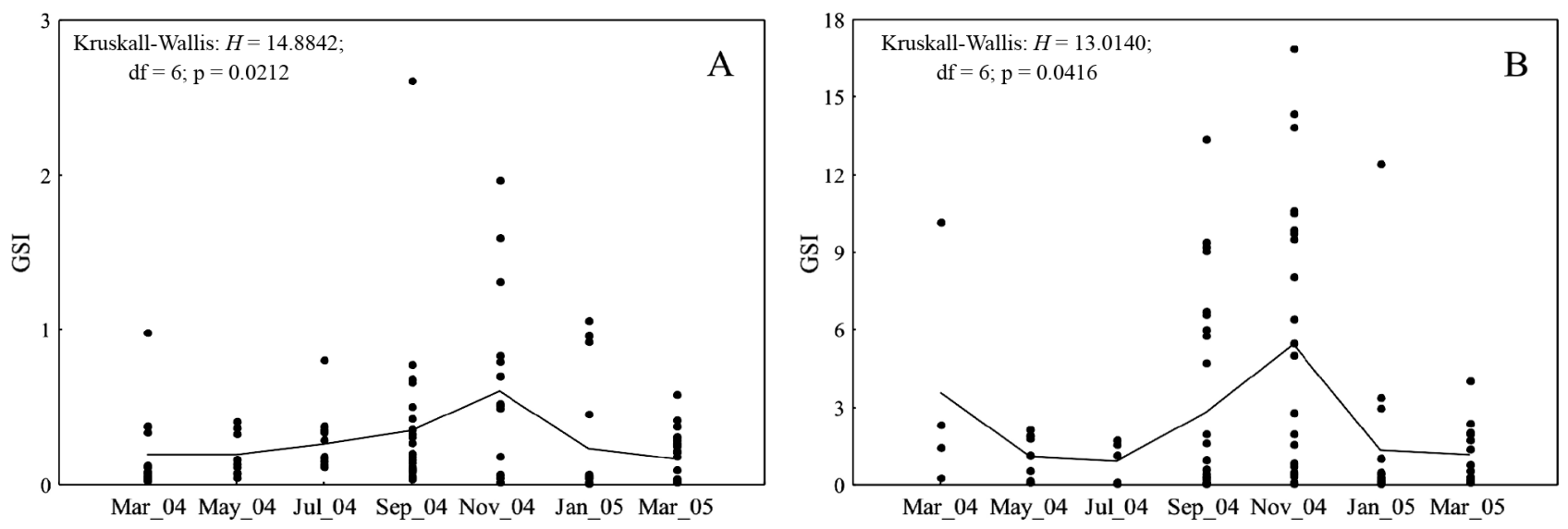

Fig. 4. Individual (black dots) and average (line) values of gonadosomatic index (GSI) of (A) males and (B) females of Neoplecostomus microps, captured in the Macaé River, southeastern Brazil, from March 2004 through March 2005 


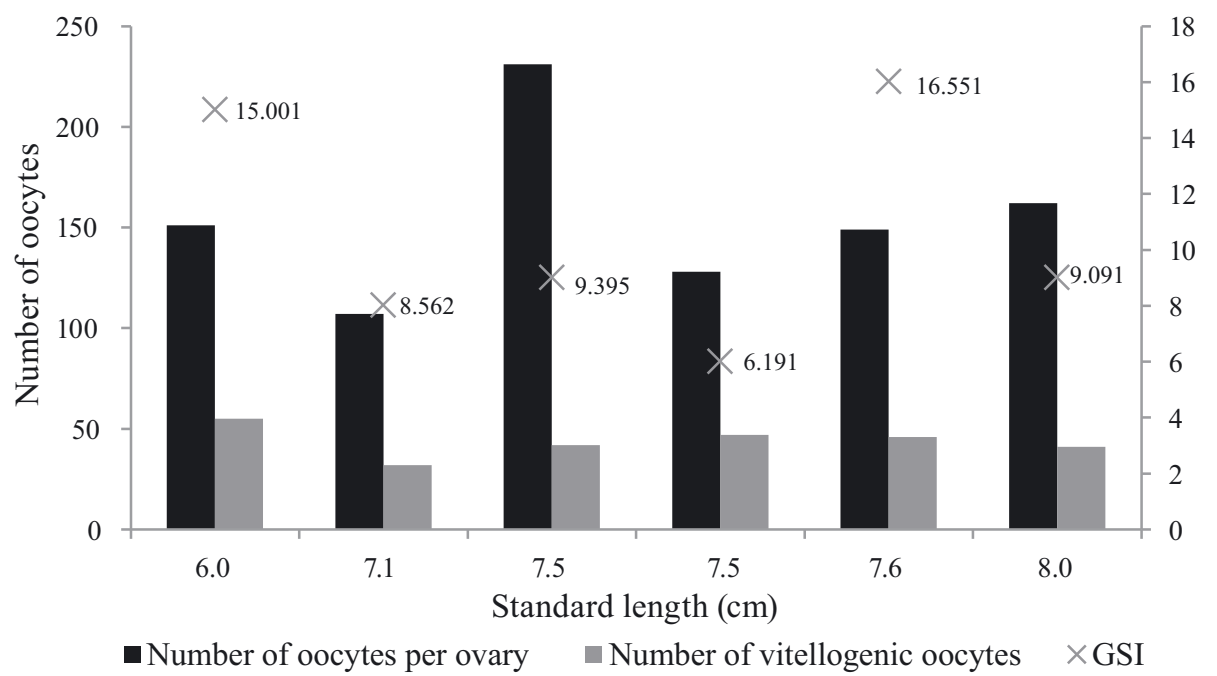

Fig. 5. Distribution of the relative frequencies of oocyte diameter classes in 6 mature females of Neoplecostomus microps in the Macaé River, southeastern Brazil. GSI: gonadosomatic index

tember $(\mathrm{p}=0.029)$, and November $2005(\mathrm{p}=0.014)$. For females, it was verified that November 2004 differed significantly from September $2004(p=0.013)$, January 2005 ( $\mathrm{p}=0.001)$, and March $2005(\mathrm{p}=0.041)$.

The higher values of rainfall and GSI for males and females occurred in November but were not significantly correlated for the sampling period. Vitellogenic oocytes presented diameters between 2.017 and $3.448 \mathrm{~mm}$. The absolute fecundity from 6 females (6.02-8.00 cm standard length) of $N$. microps presented a range of 32 to 55 oocytes (mean $\pm \mathrm{SD}=$ $43.83 \pm 7.62$ ) (Table 1 ). The distribution of oocyte diameter classes (Fig. 5) revealed the existence of 3 oocyte groups. The first was composed of reserve oocytes, with diameters between 0.068 and $0.948 \mathrm{~mm}$. The second consisted of developing oocytes, with diameters between 1.034 and $1.896 \mathrm{~mm}$. The third was composed of mature oocytes, which probably would be spawned, measuring between 2.063 and $3.448 \mathrm{~mm}$.

\section{DISCUSSION}

The sex ratio can show temporal variation as a result of successive events that affect males and females differently (Vazzoler 1996). In this study, the sex ratio did not differ from 1:1 during the study period, conforming to the expected null hypothesis. For the same species, Braga et al. (2008) found a sex ratio of approximately 1:3 favoring females, but samples were collected at 4 different rivers, which may have influenced the result. Considering the sex ratio among the length classes, we found only males in the largest length classes, suggesting differential mortality (e.g. higher energetic cost to produce oocytes) or activity (e.g. higher exposure of males in the rapids) between the sexes in the studied sections of the Macaé River. Males also reaching the largest sizes in other species of Loricariidae were found by Mazzoni \& Caramaschi $(1995,1997)$ for Hypostomus affinis and H. luetkeni and by Suzuki et al. (2000) for $H$. ternetzi and Megalancistrus aculeatus. Nikolsky (1963) reported that males tend to be larger than females in species that defend their eggs, larvae, and young in the nest against other fish and predators. Although females and males present similar growth, larger body size in males of Neoplecostomus microps may be a useful strategy to defend and/or compete for appropriate spawning sites and also to protect the offspring in development in the eggs, as shown by Brito et al. (2016).

The size at first gonadal maturation is an important reproductive tactic because it is closely related to growth, presenting spatial-temporal intraspecific variations related to biotic and abiotic conditions of the occupied area or the period when the population is subject to these factors (Vazzoler 1996). The maturation expresses the interaction between the genetic background and environmental influences and provides evidence of geographic and/or reproductive isolation of fish populations (Begg 2005). The length of maturation may be directly affected through changes in the quantity of energy reserves available for gonad development (Morgan 2004) or indirectly via changes in growth, which in turn influence the triggering of maturation (Engelhard \& Heino 2004). In this study, the size at sexual maturity found for $N$. microps was consistent with that registered by Braga et al. (2008) for the same species in the upper stretches of the Paraíba do Sul river basin, located in São Paulo State, southeastern Brazil, which seems to be a conservative parameter for the species. 
The reproductive period of $N$. microps was associated with the spring and summer period (until $6 \mathrm{mo}$ ). The large reproductive period of $N$. microps in the Serra do Mar stream was not different from that of the Serra da Mantiqueira population in São Paulo State (Braga et al. 2008). The Serra do Mar is exposed to frequent and strong orogenic rains, and the pluviometric index in Macaé River localities reaches annual means exceeding 2000 mm, according to the Agência Nacional de Águas (2006). A prolonged reproductive period, with increased reproductive activity coinciding with the rainy season, was observed by Brito (2007) for other species of the Macaé River (e.g. Characidium cf. vidali, Astyanax cf. intermedius, and Schizolecis guntheri). N. microps shows a sharp increase in reproductive effort and spawning in November that coincides with the onset of rains, but a significant correlation in the tests between pluviometric data and GSI was not observed. In the stretches that $N$. microps inhabits, the incidence of flash floods in spring and summer is probably the seasonal factor that most influences the reproductive patterns of the ichthyofauna. A continuous or extensive reproductive period could increase the probability of success in recruiting (Matthews 1998) and be a useful strategy to overcome hydrologically unstable environments such as streams and rivers of the Brazilian Atlantic Forest.

The variations in the stages of gonad maturity and GSI values showed higher frequencies of mature individuals and higher values of GSI in November, suggesting a reproductive peak of $N$. microps in the Serra do Mar stream. Braga et al. (2008) verified higher GSI values in samples from October and February in the Serra da Mantiqueira. It seems plausible to assume that the 2 populations have their reproductive periods at similar times. According to LoweMcConnell (1987), in the tropics, where the annual changes in photoperiod and temperature are not very noticeable, the influence of these factors on reproduction are minimal or nonexistent. In tropical regions, such as in southeastern Brazil, the level of the rivers determines the availability of habitat and food, and rainfall seems to be the factor that most influences the reproductive cycles of fish (Vazzoler 1983, Vazzoler \& Menezes 1992, Vazzoler et al. 1997, Agostinho et al. 2004, Bailly et al. 2008, Freitas et al. 2011). In the Macaé River, N. microps exhibits high reproductive effort in the rainy season, from November to March, when the river is subjected to sudden changes in water volume (Brito 2007). The prolonged reproductive period, low fecundity, large eggs, positive allometry, possible parental care, and repeated spawns recorded for $N$. microps suggest a strategy that maximizes parental fitness. These attributes indicate an equilibrium strategist sensu Winemiller (1989) and may also increase juvenile survivorship and reduce fluctuations in local population density.

The absolute fecundity estimated for $N$. microps in the Macaé River ranged from 42 to 55 oocytes, with mature oocytes having a mean diameter of $2.72 \mathrm{~mm}$. These values were very close to those reported by Braga et al. (2008). This corroborates the hypothesis of more than 1 female spawning on the same stone by Brito et al. (2016), where up to 375 eggs per stone were registered. The low fecundity in loricariid species was reported in several publications (Mazzoni \& Caramaschi 1997, Suzuki et al. 2000, Schmidt 2001, Braga et al. 2009), demonstrating that egg size influences offspring quality (Sargent et al. 1987), since both correlative and experimental evidence has shown that several measures of fitness are positively related to egg size (Kolm \& Ahnesjö 2005). For species that reside in spatially limited and unstable environments, such as stream and river channels, the increase in oocyte diameter and the reduction of fecundity can be understood as tactical advantages for larval survival. The pattern of at least 2 batches of oocytes recruited for vitellogenesis was similar to the loricariids Pseudotothyris obtusa (Menezes et al. 2000) and Pareiorhina rudolphi (Braga et al. 2009), both smaller than $N$. microps.

Considering $N$. microps populations in the Serra do Mar (present study) and the Serra da Mantiqueira (Braga et al. 2008), we observed similar reproductive behavior. It is possible that in environments with seasonal variation that is less predictable and strongly influenced by short-duration events, such as orogenic rains and subsequent flash floods, the immediate conditions are more important than regional seasonal changes for reproduction in small streams.

Acknowledgements. We thank all the members of the Laboratório de Ecologia de Peixes (UFRJ) who helped us with the field and laboratory work. We are also grateful to the inhabitants of the Macaé River basin for their hospitality, especially Sérgio Almeida, Geraldo Craik, Joceline Craik, Márcio Nascimento Silva and Renaldo, Morais and Gracinha. We thank CNPq and FAPERJ for scholarships. The authors thank Bruno Eleres Soares for statistical support. The study was part of the project entitled 'Estrutura da comunidade e estratégias reprodutivas e tróficas de peixes da bacia do rio Macaé, RJ', partially financed by CNPq and FAPERJ (grant nos. 479257/2004-3 and E-26/171.672/2001, respectively). We also thank IBAMA for a collecting permit (Authorization 004/2004). 


\section{LITERATURE CITED}

Agência Nacional de Águas (2006). Available at www.ana. gov.br/

Agostinho AA, Hahn NS, Agostinho CS (1991) Ciclo reprodutivo e primeira maturação gonadal de fêmeas de Hypostomus commersonii (Valenciennes, 1840) (Siluriformes, Loricariidae) no reservatório Capivari-Cachoeira, PR. Rev Bras Biol 51:31-37

Agostinho AA, Gomes LC, Veríssimo S, Okada EK (2004) Flood regime, dam regulation and fish in the upper Paraná River: effects on assemblage attributes, reproduction and recruitment. Rev Fish Biol Fish 14:11-19

Ayres M, Ayres M Jr, Ayres DL, Santos AAS (2007) BioEstat 5.0: aplicações estatísticas nas áreas das Ciências Biomédicas. Sociedade Civil Mamirauá, Belém

Bailly D, Agostinho AA, Suzuki HI (2008) Influence of the flood regime on the reproduction of fish species with different reproductive strategies in the Cuiabá River, upper Pantanal, Brazil. River Res Appl 24:1218-1229

Begg GA (2005) Life history parameters. In: Cadrin SX, Friedland KD, Waldman, JR (eds) Stock identification methods: applications in fishery science. Elsevier Academic Press, Burlington, MA, p 119-150

Bizerril CRSF (1995) Descrição de uma nova espécie de Neoplecostomus (Loricariidae, Neoplecostominae) com uma sinópse da composição taxonômica dos Loricariidae no leste brasileiro. Braz Arch Biol Technol 38:693-704

Braga FMS, Gomiero LM, Souza UP (2008) Aspectos da reprodução e alimentação de Neoplecostomus microps (Loricariidae, Neoplecostominae) na microbacia do Ribeirão Grande, serra da Mantiqueira oriental (Estado de São Paulo). Acta Sci Biol Sci 30:455-463

Braga FMS, Gomiero LM, Souza UP (2009) Biologia populacional de Pareiorhina rudolphi (Loricariidae, Hypostominae) na microbacia do Ribeirão Grande, serra da Mantiqueira oriental, Estado de São Paulo. Acta Sci Biol Sci 31:79-88

Brito MFG (2007) Atividade reprodutiva dos peixes do Rio Macaé (RJ) em função do gradiente longitudinal. PhD thesis, Universidade Federal do Rio de Janeiro, Rio de Janeiro

Brito MFG, Lazzarotto H, Caramaschi EP (2016) Life-history features of a rapids-dwelling loricariid catfish from Atlantic forest streams, Brazil. Biota Neotrop 16:e20150068

Buckup PA (1999) Sistemática e biogeografia de peixes de riachos. In: Caramaschi EP, Mazzoni R, Peres-Neto PR (eds) Ecologia de peixes de riachos, Vol 6. PPGE-UFRJ, Rio de Janeiro, p 91-138

Buckup PA (2007) Família Loricariidae: Neoplecostominae. In: Buckup PA, Menezes NA, Ghazzi MS (eds) Catálogo das espécies de peixes de água doce do Brasil, Série Livros 23. Museu Nacional, Rio de Janeiro, p 82

Dei Tos C, Agostinho AA, Suzuki HI (1997) Population structure and reproductive biology of Loricariichthys platymetopon (Siluriformes, Pisces) in the upper river Paraná. Braz Arch Biol Technol 40:793-807

Delariva RL, Agostinho AA (2001) Relationship between morphology and diets of six neotropical loricariids. J Fish Biol 58:832-847

Engelhard GH, Heino M (2004) Maturity changes in Norwegian spring-spawning herring before, during, and after a major population collapse. Fish Res 66:299-310

Eschmeyer WN, Fricke R, Van der Laan R (2016) Catalog of fishes: genera, species, references. Available at http:// researcharchive.calacademy.org/research/ichthyology/ catalog/fishcatmain.asp) (accessed 25 May 2016)

Ferraris CJ Jr (2003a) Family Loricariidae. In: Reis RE, Kullander SO, Ferraris CJ Jr (eds) Check list of the freshwater fishes of South and Central America. EDIPUCRS, Porto Alegre, p 318

Ferraris CJ Jr (2003b) Subfamily Neoplecostominae. In: Reis RE, Kullander SO, Ferraris CJ Jr (eds) Check list of the freshwater fishes of South and Central America. EDIPUCRS, Porto Alegre, p 319-320

Flecker AS (1992) Fish trophic guilds and the structure of a tropical stream: weak direct vs. strong indirect effects. Ecology 73:927-940

Freitas TMS, Almeida VHC, Montag LFA, Rocha RM, Fontoura NF (2011) Seasonal changes in the gonadossomatic index, allometric condition factor and sex ratio of an auchenipterid catfish from eastern Amazonia. Neotrop Ichthyol 9:839-847

Froese R (2006) Cube law, condition factor and weightlength relationships: history, meta-analysis and recommendations. J Appl Ichthyol 22:241-253

*Guimarães-Cruz RJ, Santos JE, Santos GB (2005) Gonadal structure and gametogenesis of Loricaria lentiginosa Isbrücker (Pisces, Teleostei, Siluriformes). Rev Bras Zool 22:556-564

Kolm N, Ahnesjö I (2005) Do egg size and parental care coevolve in fishes? J Fish Biol 66:1499-1515

Langeani F (1990) Revisão do gênero Neoplecostomus Eigenmann \& Eigenmann, 1888, com a descrição de quatro novas espécies do sudeste brasileiro (Ostariophysi, Siluriformes, Loricariidae). Comun Mus Cienc Tecnol PUCRS Ser Zool 3:3-31

Lleonart J, Salat J, Torres GJ (2000) Removing allometric effects of body size in morphological analysis. J Theor Biol 205:85-93

Lowe-McConnell RH (1987) Ecological studies in tropical fish communities. Cambridge University Press, Cambridge

Matthews WJ (1998) Patterns in freshwater fish ecology. Chapman \& Hall, New York, NY

*Mazzoni R, Caramaschi EP (1995) Size structure, sex ratio, and onset of sexual maturity of two species of Hypostomus. J Fish Biol 47:841-849

Mazzoni R, Caramaschi EP (1997) Observations on the reproductive biology of female Hypostomus luetkeni Lacépède, 1803. Ecol Freshwat Fish 6:53-56

Menezes MS, Caramaschi EP (1994) Características reprodutivas de Hypostomus grupo $H$. punctatus no rio Ubatiba, Marica, RJ (Osteichthyes, Siluriformes). Rev Bras Biol 54:503-513

Menezes MS, Takeuti DF, Aranha JMR, Verani JR (2000) Desenvolvimento Gonadal de machos e fêmeas de Pseudotothyris obtusa (Ribeiro, 1911) (Loricariidae, Hypoptopomatinae). Acta Biol Parana 29:89-100

Morgan MJ (2004) The relationship between fish condition and the probability of being mature in American plaice (Hippoglossoides platessoides). ICES J Mar Sci 61:64-70

Nikolsky GV (1963) The ecology of fishes. Academic Press, London

Núñez J, Duponchelle F (2009) Towards a universal scale to assess sexual maturation and related life history traits in oviparous teleost fishes. Fish Physiol Biochem 35: 167-180

Power ME (1984) Depth distributions of armored catfish: predator-induced resource avoidance? Ecology 65: $523-528$ 
Sakurai A, Sakamoto Y, Mori F, Loiselle PV (1993) Aquarium fish of the world: the comprehensive guide to 650 species. Chronicle Books, San Francisco, CA

Sargent RC, Taylor PD, Gross MR (1987) Parental care and the evolution of egg size in fishes. Am Nat 129:32-46

Schaefer SA, Lauder GV (1986) Historical transformation of functional design: evolutionary morphology of feeding mechanisms in loricariid catfishes. Syst Zool 35:489-508

Schmidt RE (2001) Loricaria cataphracta: parental care and description of early larvae. Ichthyol Explor Freshwat 12: 235-240

Sterba G, Mills D (eds) (1983) The aquarium encyclopedia. The MIT Press, Cambridge, MA

Suzuki HI, Agostinho AA, Winemiller KO (2000) Relationship between oocyte morphology and reproductive strategy in loricariid catfishes of the Paraná River, Brazil. J Fish Biol 57:791-807

Vazzoler AEAM (1983) Comportamento Reprodutivo em peixes de água doce. In: I Encontro Paulista de Etologia.

Editorial responsibility: Victor Benno Meyer-Rochow, Oulu, Finland
Funep, São Paulo, p 195-207

Vazzoler AEAM (1996) Biologia da reprodução de peixes teleósteos: teoria e prática. Eduem, Maringá

Vazzoler AEAM, Menezes NA (1992) Síntese de conhecimentos sobre o comportamento reprodutivo dos Characiformes da América do Sul (Teleostei, Ostariophysi). Rev Bras Biol 52:627-640

Vazzoler AEAM, Lizama MAP, Inada P (1997) Influências ambientais sobre a sazonalidade reprodutiva. In: Vazzoler AEAM, Agostinho AA, Hahn NS (eds) A planície de inundação do Alto rio Paraná: aspectos físicos, biológicos e socioeconômicos. Eduem, Maringá, p 267-280

Winemiller KO (1989) Patterns of variation in life history among South American fishes in seasonal environments. Oecologia 81:225-241

Zawadzki CH, Pavanelli CS, Langeani F (2008) Neoplecostomus (Teleostei: Loricariidae) from the upper rio Paraná basin, Brazil, with description of three new species. Zootaxa 1757:31-48

Submitted: June 29, 2018; Accepted: February 6, 2019 Proofs received from author(s): March 29, 2019 